\title{
SINDROME DE "NUTCRACKER"
}

\section{Pôster}

Autores deste trabalho:

Maria Cristina de Andrade: UNIFESP-EPM

Leão FVF: UNIFESP-EPM

Tanaka MAB: UNIFESP-EPM

Leslie B: UNIFESP-EPM

Cançado MAP: UNIFESP-EPM

Área do Trabalho: Pediatria

Número de inscrição: 5597

Data da submissão:01/09/2016 às 10:21

\section{Justificativa}

A síndrome de "nutcracker" (síndrome do quebra-nozes) foi descrita pela primeira vez por Chait e De Scheepper em 1950. Grant em 1937 descreveu os achados anatômicos desta síndrome. Ela se caracteriza anatomicamente pela compressão da veia renal esquerda no seu trajeto entre a aorta abdominal e a artéria mesentérica superior. Esta compressão pode ocasionar hipertensão da veia renal esquerda, com manifestação clínica de dor abdominal e hematúria.

\section{Objetivo(s)}

Relato de caso

\section{Método(s)}

relato de caso

\section{Resultado(s)}

Criança do sexo masculino, com II anos de idade, assintomática, encaminhada ao nefrologista pediátrico por hematúria microscópica e discreta proteinúria no exame de rotina. Apresentava ao exame físico varicocele à esquerda. O ultrassom de vias urinárias foi normal. Após descartar várias etiologias de hematúria e proteinúria, foi solicitado ultrassom Doppler de veia renal esquerda que mostrou uma angulação significativa da 
artéria mesentérica superior em relação à aorta, exercendo efeito compressivo sobre a veia renal esquerda que apresentava-se ectasiada a montante. Ressonância magnética de vasos renais com discreta compressão na veia renal esquerda pela artéria mesentérica superior com colaterais venosas na região para-aórtica esquerda, associadas à proeminência do plexo pampiniforme da bolsa testicular deste lado. A criança foi submetida a correção cirúrgica da varicocele.

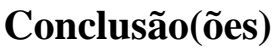

A síndrome de "nutcracker" pode ser assintomática, apresentar hematúria micro e macroscópica, proteinúria, dor lombar ou no flanco esquerdo, dor na região pélvica à esquerda por congestão venosa, varicocele ou varizes vulvares nas mulheres. Acredita-se que a hematúria é resultante da hipertensão venosa com alteração hemodinâmica que condicionam a ruptura de pequenos vasos sanguíneos. A prevalência de "nutcracker" na infância é desconhecida sendo subdiagnosticada. A abordagem terapêutica em criança deve ser conservadora pois pode haver remissão espontânea durante o crescimento devido ao aumento do tecido adiposo e circulação colateral. Os tratamentos cirúrgicos são discutíveis, variam de acordo com o caso. "Stent' endovascular", "by-pass'"veia renal esquerda - veia cava inferior, autotransplante, entre outras técnicas. 